\title{
A structural MRI study of motor conversion disorder: evidence of reduction in thalamic volume
}

\author{
T R Nicholson, ${ }^{1}$ S Aybek, ${ }^{1}$ M J Kempton, ${ }^{2}$ E M Daly, ${ }^{3}$ D G Murphy, ${ }^{3}$ A S David, ${ }^{1}$ \\ R A Kanaan ${ }^{4}$
}

${ }^{1}$ Section of Cognitive Neuropsychiatry, Institute of Psychiatry, King's College London, London, UK

${ }^{2}$ Department of Neuroimaging, Institute of Psychiatry, King's College London, London, UK ${ }^{3}$ Department of Forensic and Neurodevelopmental Science, Institute of Psychiatry, King's College London, London, UK ${ }^{4}$ Department of Psychiatry,

University of Melbourne, Austin Hospital, Melbourne, Australia

\section{Correspondence to}

Dr Tim Nicholson,

Section Cognitive

Neuropsychiatry, PO Box 68, Institute of Psychiatry, Denmark Hill, London SE5 8AF, UK timothy.nicholson@kcl.ac.uk

TRN and SA contributed equally to this work.

Received 21 January 2013 Revised 6 August 2013

Accepted 20 August 2013

\section{ABSTRACT}

Objective To investigate potential abnormalities in subcortical brain structures in conversion disorder (CD) compared with controls using a region of interest (ROI) approach.

Methods Fourteen patients with motor CD were compared with 31 healthy controls using high-resolution MRI scans with an ROI approach focusing on the basal ganglia, thalamus and amygdala. Brain volumes were measured using Freesurfer, a validated segmentation algorithm.

Results Significantly smaller left thalamic volumes were found in patients compared with controls when corrected for intracranial volume. These reductions did not vary with handedness, laterality, duration or severity of symptoms.

Conclusions These differences may reflect a primary disease process in this area or be secondary effects of the disorder, for example, resulting from limb disuse. Larger, longitudinal structural imaging studies will be required to confirm the findings and explore whether they are primary or secondary to CD.

\section{INTRODUCTION}

Conversion disorder (CD) describes the presence of neurological symptoms that are not due to neurological disease and are thought to be psychological in origin. It is assumed that patients have normal brain anatomy and the disorder is one of 'function'; structural brain abnormalities of potential aetiological relevance would generally preclude the diagnosis. However, it is possible there are subtle neuroanatomical abnormalities that are only discernable at the group level rather than in individual patients. There has, to date, been one study of subcortical brain structures in motor CD, reporting reduced thalamic, caudate and lentiform nuclei volume in 12 patients with unilateral limb weakness compared with 12 controls using manual anatomical labelling methods. ${ }^{1}$ We aimed to confirm these volume differences using a region-of-interest (ROI) approach on the thalamus and basal ganglia of high-resolution MRI scans of patients with motor CD and healthy controls. We also investigated the amygdala as an additional ROI, given that multiple functional imaging studies suggest a role for this structure in the aetiology of CD including suggestions of links between its role in emotion processing and the motor system. ${ }^{2-4}$

\section{METHODS}

Fifteen patients with Diagnostic and Statistical Manual of Mental Disorders (DSM)-IV diagnoses (by consultant neuropsychiatrists) of motor CD and 31 healthy controls were recruited. Subjects with major mental health disorder (any DSM axis 1 disorder in controls; psychosis, bipolar disorder or major depression in patients) or neurological illness were excluded. Groups were matched for gender (patients 67\%, controls 61\% women), age (patients mean 37 years, controls mean 32 years), handedness (patients 92\%, controls 96\% right-handed) and IQ (patients mean 108, controls mean 112). The patients all had motor weakness as their primary (most disabling) symptom at the time of scanning and were in the first episode of their disorder, that is, had not recovered from their initial symptoms (although motor symptoms did often progress during these episodes). Twelve patients initially had predominantly asymmetrical symptoms (eight had both arm and leg weakness (hemiparesis), three had leg only and one arm only) and three patients had predominantly symmetrical symptoms affecting legs only (paraparesis). All of the patients with initial asymmetrical leg weakness later developed symmetrical paraparesis and the patient with asymmetrical arm weakness later developed a mild tetraparesis. The mean duration of symptoms at the time of scanning was just over a year (14 months) with a range of 3 months to 3 years. At the time of scanning, all patients were still symptomatic: for four patients, symptoms were minor (little impairment of function); for seven, they were moderate (significant impairment of function); and for four, they were major (major impairment of function and little or no improvement from their peak disability). The median impairment was moderate. Subjects gave informed written consent and the study was approved by the local Research Ethics Committee (ref 07/H0805/33).

MRIs were acquired on all subjects using a General Electric three Tesla Signa HDX scanner, using a T1-weighted, steady-state, gradient-spoiled, gradient recalled echo acquisition. Images were acquired in the coronal plane with $\mathrm{TE}=2.8 \mathrm{~ms}$, $\mathrm{TR}=7.1 \mathrm{~ms}, \mathrm{TI}=450 \mathrm{~ms}$, flip angle $20^{\circ}$, bandwidth $31.25 \mathrm{KHz}$ and a $256 \times 256 \times 200$ image matrix. The field of view and slice thickness were $280 \mathrm{~mm}$ and $1.4 \mathrm{~mm}$ respectively, yielding a final image resolution of $1.1 \times 1.1 \times 1.4 \mathrm{~mm}$.

A ROI approach was taken and eight subcortical anatomical structures were chosen on the basis of previous findings as detailed above. Our selected 
regions were, bilaterally, the caudate and lentiform nuclei and the thalamus and the amygdala. FreeSurfer software V.5.00 (http://www.surfer.nmr.mgh.harvard.edu/fswiki) was used to identify and measure subcortical structures. This is an automated procedure validated against non-automated and other automated methods. ${ }^{5} 6$ Unblinded visual inspection was conducted to exclude obvious segmentation errors; this occurred in only one subject (a patient) who was excluded, leading to a final total of 14 patients for analysis. An analysis of covariance design was used to covary for intracranial volume with handedness entered as a fixed factor. Correlations between clinical features and brain volumes were explored in patients.

\section{RESULTS}

There were significant reductions in thalamic volume bilaterally in patients compared with controls (left thalamus $\mathrm{t}_{(44)}=3.80$, $\mathrm{p}=0.001$, right thalamus $\left.\mathrm{t}_{(44)}=3.43, \mathrm{p}=0.002\right)$. Intracranial volume was also significantly reduced in patients, however $\left(t_{(44)}=2.70, p=0.012\right)$, and when this was entered as a covariate, the thalamic reductions remained significant for the left thalamus $\left(\mathrm{F}_{(1,43)}=5.44, \mathrm{p}=0.024\right)$ and was borderline significant for the right thalamus $\left(\mathrm{F}_{(1,43)}=4.01, \mathrm{p}=0.052\right)$. After correction for intracranial volume, there was a significant $\left(\mathrm{F}_{(1,43)}=4.14\right.$, $\mathrm{p}=0.048$ ) reduction in the volume of the left, but not the right, lentiform nucleus. There were no other ROI differences. Details of these comparisons are given in table 1. Covarying for handedness did not significantly alter these results. Within patients, there were no significant correlations between thalamic volumes and laterality, duration or severity of symptoms.

\section{DISCUSSION}

The finding of a smaller volume of the thalamus in CD compared with controls could either be evidence of a primary disease process in this area or could represent a secondary effect of the disorder. Support for a primary process comes from a

Table 1 Volumes of regions of interest (ROI) for patients and controls

\begin{tabular}{|c|c|c|c|c|c|}
\hline ROI & Subject & $\begin{array}{l}\text { Mean vol } \\
\left(\mathrm{mm}^{3}\right)\end{array}$ & SD & $\begin{array}{l}t \text { test ( } p \\
\text { value) }\end{array}$ & $\begin{array}{l}\text { ANCOVA } \\
\text { covarying for } \\
\text { ICV ( } p \text { value) }\end{array}$ \\
\hline Left thalamus & $\begin{array}{l}\text { Control } \\
\text { Patient }\end{array}$ & $\begin{array}{l}8370 \\
7180\end{array}$ & $\begin{array}{l}971 \\
1040\end{array}$ & 0.001 ** & $0.024^{*}$ \\
\hline $\begin{array}{l}\text { Right } \\
\text { thalamus }\end{array}$ & $\begin{array}{l}\text { Control } \\
\text { Patient }\end{array}$ & $\begin{array}{l}7900 \\
6970\end{array}$ & $\begin{array}{l}817 \\
893\end{array}$ & $0.002^{* *}$ & 0.052 \\
\hline $\begin{array}{l}\text { Left lentiform } \\
\text { nucleus }\end{array}$ & $\begin{array}{l}\text { Control } \\
\text { Patient }\end{array}$ & $\begin{array}{l}7390 \\
7060\end{array}$ & $\begin{array}{l}958 \\
899\end{array}$ & 0.26 & $0.048^{*}$ \\
\hline $\begin{array}{l}\text { Right } \\
\text { lentiform } \\
\text { nucleus }\end{array}$ & $\begin{array}{l}\text { Control } \\
\text { Patient }\end{array}$ & $\begin{array}{l}6830 \\
6340\end{array}$ & $\begin{array}{l}848 \\
859\end{array}$ & 0.08 & 0.39 \\
\hline $\begin{array}{l}\text { Left caudate } \\
\text { nucleus }\end{array}$ & $\begin{array}{l}\text { Control } \\
\text { Patient }\end{array}$ & $\begin{array}{l}3560 \\
3350\end{array}$ & $\begin{array}{l}578 \\
456\end{array}$ & 0.19 & 0.41 \\
\hline $\begin{array}{l}\text { Right } \\
\text { caudate } \\
\text { nucleus }\end{array}$ & $\begin{array}{l}\text { Control } \\
\text { Patient }\end{array}$ & $\begin{array}{l}3370 \\
3260\end{array}$ & $\begin{array}{l}605 \\
479\end{array}$ & 0.53 & 0.09 \\
\hline $\begin{array}{l}\text { Left } \\
\text { amygdala }\end{array}$ & $\begin{array}{l}\text { Control } \\
\text { Patient }\end{array}$ & $\begin{array}{l}1640 \\
1540\end{array}$ & $\begin{array}{l}236 \\
239\end{array}$ & 0.20 & 0.67 \\
\hline $\begin{array}{l}\text { Right } \\
\text { amygdala }\end{array}$ & $\begin{array}{l}\text { Control } \\
\text { Patient }\end{array}$ & $\begin{array}{l}1710 \\
1610\end{array}$ & $\begin{array}{l}223 \\
200\end{array}$ & 0.10 & 0.76 \\
\hline $\begin{array}{l}\text { Intracranial } \\
\text { volume (ICV) }\end{array}$ & $\begin{array}{l}\text { Control } \\
\text { Patient }\end{array}$ & $\begin{array}{l}1610000 \\
1440000\end{array}$ & $\begin{array}{l}187000 \\
210000\end{array}$ & $0.01^{*}$ & N/A \\
\hline
\end{tabular}

functional imaging study that found reduced activation of the thalamus (and other basal ganglia regions) in CD patients when in a symptomatic state compared with after recovery of function. ${ }^{7}$ This would be compatible with the thalamus' known function in relaying and integrating motor output and the proposed role of striatothalamocortical premotor loops in intentional movement generation ${ }^{8}$ and subjective sensations of effort and volition. ${ }^{9}$ A primary process would have significant implications for the potential aetiology and conceptualisation of $\mathrm{CD}$ and challenge the easy distinction between functional and structural as commonly understood in this condition. ${ }^{10}$

However, the differences are also explicable by the secondary effects of chronic limb immobility as there is some evidence of similar thalamic volume losses after limb amputation (although the authors of that study focus on deafferentation rather than a lack of motor activity as the possible mechanism influencing neuronal plasticity and therefore changes in thalamic volume). ${ }^{11}$ If the differences were secondary, this would be a strong indicator of the severity of motor CD in terms of the level of immobility. This would counter a widely held belief that CD patients are often significantly less symptomatic when not in the presence of others, especially assessing or treating clinicians. That belief finds support from recent evidence from CD with tremor, where patient diary records of symptoms were significantly higher than those recorded by $24 \mathrm{~h}$ monitoring (actigraphy) when compared with 'organic' tremor patients who also overestimate symptom levels but by less than half as much. ${ }^{12}$ Therefore, at least for motor CD patients, our study could indicate that the level of dysfunction was sufficient to result in the same order of plastic change to the subcortical motor system as seen in amputation. However, the lack of correlation between thalamic volume loss and the clinical variables of symptom duration and severity in our study does not support the differences being secondary to immobility (though as we only had $13 \%$ power to detect the strongest correlation $(r=0.22)$, this could be a type 2 error).

There have been two other volumetric studies of differences in $\mathrm{CD}$, both focussed on the cortical motor system. One found evidence for increased thickness of the premotor cortex ${ }^{13}$ another found decreased thickness of the motor cortex. ${ }^{14}$ While we note the consistency of these with the premotor activation and motor deactivation of our functional MRI study, ${ }^{2}$ the primary or secondary nature of these differences is equally unclear.

Larger longitudinal studies could address this, ideally involving rescanning postrecovery, along with detailed correlations of volume changes with symptom levels and other potential confounders, such as pain, depression and anxiety, which have been associated with structural brain changes. Functional imaging at the same time periods could also help disentangle whether such changes were secondary to the disorder or potentially of more aetiological relevance.

Contributors TRN conceived the study, acquired the data, performed the ROI analysis and wrote the manuscript. SA, EMD and DGM conceived the study, acquired the data and reviewed the manuscript. MJK supervised the Freesurfer analysis and reviewed the manuscript. ASD and RAK conceived the study and reviewed the manuscript.

Funding Medical Research Council (MRC) Strategic (Milstein) grant.

Competing interests TRN, ASD and RAK were supported by an MRC Strategic (Milstein) grant. SA was supported by the Swiss National Research Foundation (Advanced researcher grant). MJK is funded by an MRC Career Development Fellowship (grant number MR/J008915/1). ASD is also supported by the National Institute for Health Research (NIHR) Mental Health Biomedical Research Centre at the South London and Maudsley NHS Foundation Trust and the Institute of Psychiatry, King's College London.

Ethics approval Local Research Ethics Committee (ref 07/H0805/33). 
Provenance and peer review Not commissioned; externally peer reviewed.

\section{REFERENCES}

1 Atmaca M, Aydin A, Tezcan E, et al. Volumetric investigation of brain regions in patients with conversion disorder. Prog Neuropsychopharmacol Biol Psychiatry 2006;30:708-13.

2 Kanaan RA, Craig TK, Wessely SC, et al. Imaging repressed memories in motor conversion disorder. Psychosom Med 2007;69:202-5.

3 Voon V, Brezing C, Gallea C, et al. Emotional stimuli and motor conversion disorder. Brain 2010;133:1526-36.

4 Voon V, Gallea C, Hattori N, et al. The involuntary nature of conversion disorder. Neurology 2011;74:223-8.

5 Fischl B, Salat DH, Busa E, et al. Whole brain segmentation: automated labeling of neuroanatomical structures in the human brain. Neuron 2002;33:341-55

6 Wonderlick JS, Ziegler DA, Hosseini-Varnamkhasti P, et al. Reliability of MRI-derived cortical and subcortical morphometric measures: effects of pulse sequence, voxel geometry, and parallel imaging. Neuroimage 2009;44:1324-33.
7 Vuilleumier P, Chicherio C, Assal F. Functional neuroanatomical correlates of hysterical sensorimotor loss. Brain 2001:124:1077-90.

8 Graybiel AM, Aosaki T, Flaherty AW, et al. The basal ganglia and adaptive motor control. Science 1994;265:1826-31.

9 Gandevia SC. Roles for perceived voluntary motor commands in motor control. Trends Neurosci 1987; 10:81-5.

10 Kanaan RA, Armstrong D, Wessely SC. The function of 'functional': a mixed methods investigation. J Neurol Neurosurg Psychiatry 2012:83:248-50.

11 Draganski $B$, Moser T, Lummel N, et al. Decrease of thalamic gray matter following limb amputation. Neuroimage 2006;31:951-7.

12 Parees I, Saifee TA, Kassavetis $P$, et al. Believing is perceiving: mismatch between self-report and actigraphy in psychogenic tremor. Brain 2011;135:117-23.

13 Aybek S, Nicholson TR, Draganski B, et al. Grey matter changes in motor conversion disorder. J Neurol Neurosurg Psychiatry Published Online First: 12 December 2012 doi:10.1136/jnnp-2012-304158

14 Labate A, Cerasa A, Mula M, et al. Neuroanatomic correlates of psychogenic nonepileptic seizures: a cortical thickness and VBM study. Epilepsia 2012;53:377-85. 


\title{
ANP structural MRI study of motor conversion disorder: evidence of reduction in thalamic volume
}

T R Nicholson, S Aybek, M J Kempton, et al.

J Neurol Neurosurg Psychiatry published online September 13, 2013 doi: 10.1136/jnnp-2013-305012

Updated information and services can be found at:

http://jnnp.bmj.com/content/early/2013/09/13/jnnp-2013-305012.full.html

These include:

References This article cites 13 articles, 5 of which can be accessed free at: http://jnnp.bmj.com/content/early/2013/09/13/jnnp-2013-305012.full.html\#ref-list-1

$\mathbf{P}<\mathbf{P} \quad$ Published online September 13, 2013 in advance of the print journal.

Email alerting Receive free email alerts when new articles cite this article. Sign up in service the box at the top right corner of the online article.

\author{
Topic Articles on similar topics can be found in the following collections \\ Collections \\ Somatoform disorders (40 articles) \\ Radiology (1533 articles) \\ Radiology (diagnostics) (1149 articles)
}

Notes

Advance online articles have been peer reviewed, accepted for publication, edited and typeset, but have not not yet appeared in the paper journal. Advance online articles are citable and establish publication priority; they are indexed by PubMed from initial publication. Citations to Advance online articles must include the digital object identifier (DOIs) and date of initial publication.

To request permissions go to:

http://group.bmj.com/group/rights-licensing/permissions

To order reprints go to:

http://journals.bmj.com/cgi/reprintform

To subscribe to BMJ go to:

http://group.bmj.com/subscribe/ 